\title{
Synthesis of hybrids compounds by Click Chemistry and their bioactivities
}

\section{Guillermo Valdomir ${ }^{a}$, Juan Ignacio Padrón ${ }^{b}$, Jenny Saldaña ${ }^{a}$, José Manuel Padrón ${ }^{b}$, Gloria Serra ${ }^{a}$, Eduardo Manta ${ }^{a}$, Victor S. Martín ${ }^{b}$, Danilo Davyt ${ }^{\mathrm{a}^{*}}$}

${ }^{a}$ Facultad de Química, Universidad de la República, General Flores 2124, Montevideo, Uruguay.

${ }^{b}$ Instituto Universitario de Bio-Orgánica "Antonio Gonzalez", Universidad de La Laguna, C/Astrofísico

Fracisco Sánchez 2, La Laguna, Tenerife, Spain.

*Corresponding author.Tel.:++59829290290 Fax:++59829241906 e-mail:ddavyt@fq.edu.uy

Keywords: Hybrids, Click Chemistry, Anthelmintics

\section{INTRODUCTION}

In this work, a collection of hybrid compounds of type 1 (Scheme 1) were synthesized by a convergent route as potential anthelmintic drugs.

One fragment of the hybrids is an oxazole or thiazole prepared from a serine dipeptide. ${ }^{1}$ The other domain, are a dihydropyran obtained by Prins's cyclization, functionally with ethynyl moiety by

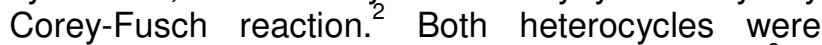
coupled using the Huisgen's reaction by a triazol. ${ }^{3}$ Cytotoxicity of hybrids were evaluated by seven cellular lines and anthelmintic activity by Nippostrongilus brasiliensis assay.

Scheme 1 Convergent synthesis of hybrids

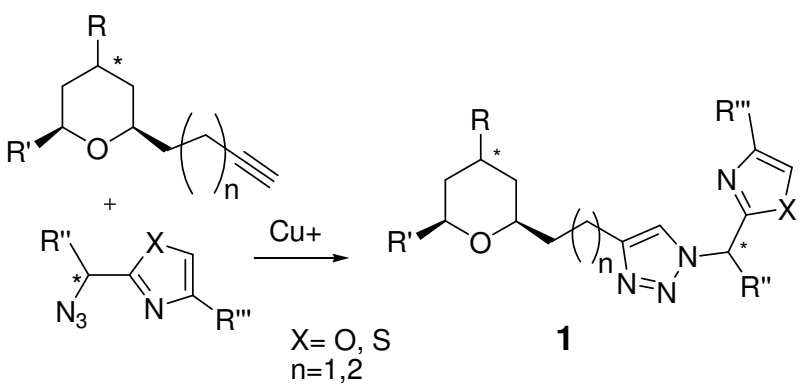

\section{RESULTS AND DISCUSSION}

A collection of six hybrids and seventeen intermediates have been prepared, and their activities are being evaluated. Most of them not showed cytotoxicity against the lines assayed and only one hybrid showed a low cytotoxicity against four lines cells. Nevertheless some of the hybrids and the intermediates assayed until now against $N$. brailiensis showed an interesting activity (see table 1).
Table 1. Some of the hybrids synthesized

\begin{tabular}{|c|c|c|c|c|c|c|}
\hline Comp & $\mathrm{n}, \mathrm{X}$ & $\mathrm{R}$ & $\mathrm{R}^{\prime}$ & $\mathrm{R} \mathrm{R}^{\prime \prime}$ & $\mathrm{R} \mathrm{R}^{\prime \prime}$ & $\begin{array}{c}\text { N.brasiliensis } \\
\mu \mathrm{M}\end{array}$ \\
\hline 2 & $1, \mathrm{O}$ & $\begin{array}{c}\mathrm{Cl}, \\
3,6 \text { dihydro } \\
2 \mathrm{H} \text {-pyran }\end{array}$ & $\mathrm{H}$ & $\mathrm{CH}_{2} \mathrm{Ph}$ & $\mathrm{CO}_{2} \mathrm{CH}_{3}$ & 10 \\
\hline 3 & $2, \mathrm{O}$ & $\begin{array}{c}\mathrm{Cl}, \\
3,6 \text { dihydro } \\
2 \mathrm{H} \text {-pyran }\end{array}$ & $\mathrm{H}$ & $\mathrm{CH}_{2} \mathrm{Ph}$ & $\mathrm{CO}_{2} \mathrm{CH}_{3}$ & $\mathbf{1 3}$ \\
\hline 4 & $1, \mathrm{O}$ & $\mathrm{OH}$ & $\mathrm{Pr}$ & $\mathrm{CH}_{2} \mathrm{Ph}$ & $\mathrm{CO}_{2} \mathrm{CH}_{3}$ & \\
\hline
\end{tabular}

\section{CONCLUSION}

Through this convergent strategy and the different methodologies that were been explored, several hybrides compounds were obtained. Preliminarily anthelmintic activity was detected for some hybrids. The hybrids have a large number of groups that can be changed to modulate this activity to achieve a more potent anthelmintic.

\section{ACKNOWLEDGEMENTS}

G.V. and D.D. would like to thanks to PEDECIBA, UdelaR, CSIC and ANII for theirs financial support during this work.

\section{REFERENCES}

${ }^{1}$ Phillips, A. J., Uto, Y., Wipf, P., Reno, M. J., Williams D. R.; Org. Lett. 2(8) (2000), 1165-1168.

${ }^{2}$ León, L. G., Miranda, P. O., Martin, V. S., Padrón, J. I., Padrón, J. M.; Bioorg. \& Med. Chem. Lett. 17 (2007) 3087-3090.

${ }^{3}$ Rostovtsev, V.V., Green, L.G., Fokin, V.V., Sharpless, K.B.; Angew. Chem. Int. Ed. 41 (2002), 2596-2599. 